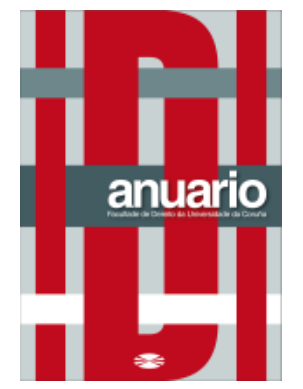

Anuario da Facultade de Dereito da Universidade da Coruña

Vol. 22 (2018), pp. 274-297

ISSNe: 2530-6324 || ISSN: 1138-039X

DOI: https://doi.org/10.17979/afdudc.2018.22.0.5187

\title{
LA FUNCIÓN NOTARIAL DE CONTROL DE LEGALIDAD. ESTADO DE LA CUESTIÓN EN EL ÁMBITO DE LAS CONDICIONES GENERALES DE LA CONTRATACIÓN Y LAS CLÁUSULAS ABUSIVAS
}

\author{
REBECA REMESEIRO REGUERO \\ Estudiante de Doctorado \\ Universidad Autónoma de Chile y Universidade da Coruña
}

Resumen: El presente artículo tiene por objetivo analizar la función notarial de control de legalidad prestando especial atención a su configuración en el ámbito de las condiciones generales de la contratación y las cláusulas abusivas a la luz de las últimas resoluciones del Tribunal Supremo y la Dirección General de los Registros y del Notariado.

Palabras clave: función notarial, control de legalidad, condiciones generales de la contratación, cláusulas abusivas.

Abstract: This article aims to analyse legality verification as a notarial function with special attention to its configuration in general conditions of contract and unfair terms fields given the latest resolutions of Tribunal Supremo and Dirección General de los Registros y del Notariado.

Keywords: notarial function, legality verification, general conditions of contract, unfair terms.

SUMARIO: I. LA FUNCIÓN NOTARIAL DE CONTROL DE LEGALIDAD. II. RECONOCIMIENTO LEGAL DE LA FUNCIÓN DE CONTROL DE LEGALIDAD. A. LEGISLACIÓN NOTARIAL. B. OTRAS DISPOSICIONES LEGALES. III. LA 
FUNCIÓN DE CONTROL DE LEGALIDAD NOTARIAL DE LAS CONDICIONES GENERALES DE LA CONTRATACIÓN Y LAS CLÁUSULAS ABUSIVAS. A. CONTROL DE INCORPORACIÓN O INCLUSIÓN. B. CONTROL DE TRANSPARENCIA. C. CONTROL DE CONTENIDO. D. EL DENOMINADO CONTROL DE EJECUCIÓN. IV. CONCLUSIONES. V. BIBLIOGRAFÍA.

\section{LA FUNCIÓN NOTARIAL DE CONTROL DE LEGALIDAD}

El control de legalidad constituye una de las funciones diferenciadoras del notariado de tipo latino ${ }^{1}$ y configura a esta clase de notariado como un órgano de control y supervisión de la legalidad del negocio jurídico que autoriza ${ }^{2}$. Esta función supone que el notario debe comprobar tanto la regularidad del negocio que se pretende documentar como la del documento notarial en que éste se plasma ${ }^{3}$. Es decir, la tarea presenta un doble aspecto: un control de legalidad formal (que atiende al documento en cuanto tal) ${ }^{4}$ y un control de legalidad material (que atiende al contenido del negocio documentado) ${ }^{5}$.

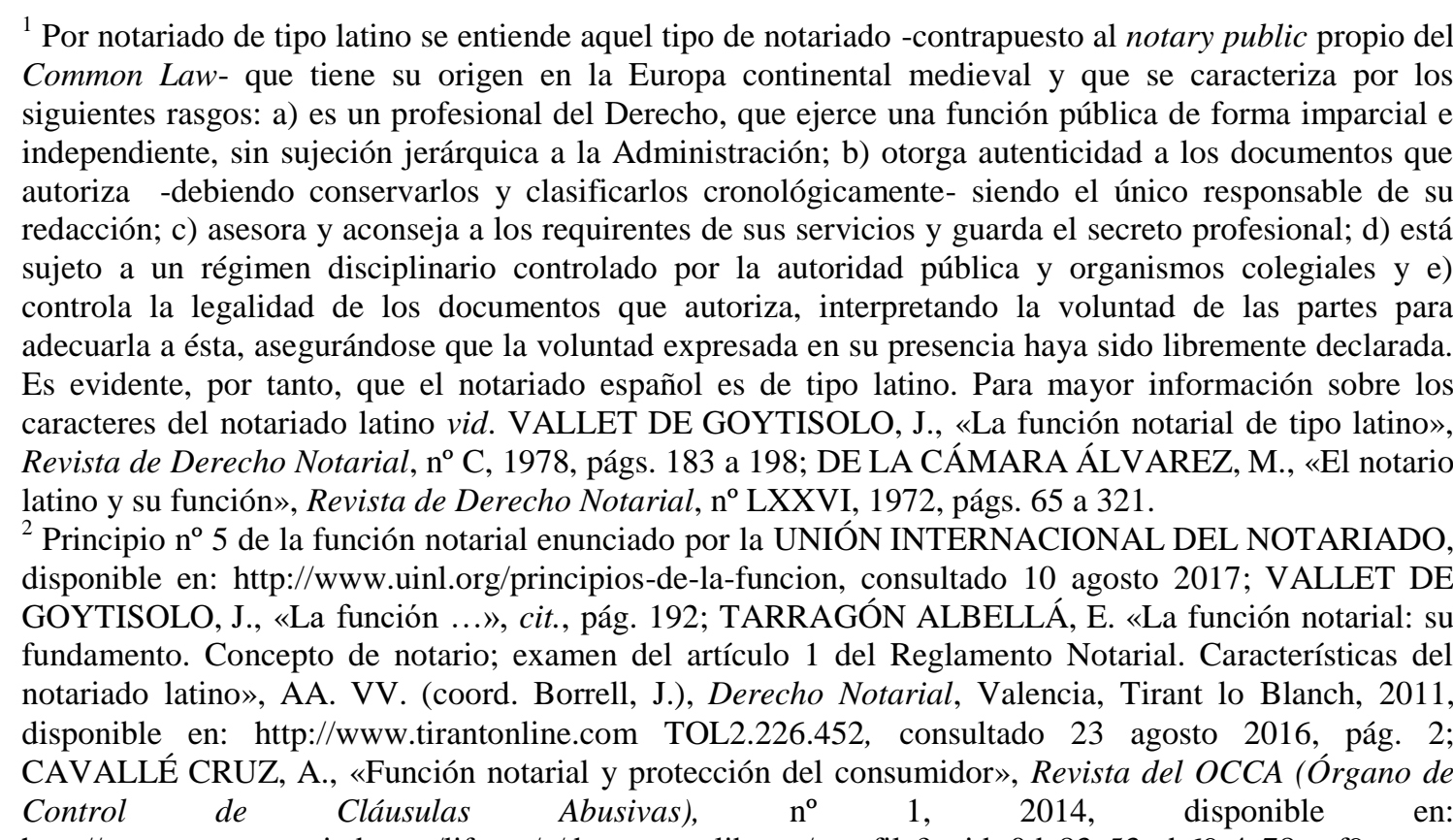
http://www.occa.notariado.org/liferay/c/document_library/get_file?uuid=0de83c53-cb69-4e78-aaf96a166f03b885\&groupId=5857552, consultado 11 enero 2018, pág. 11.

3 RUEDA PÉREZ, M. A., «La función notarial en la economía de mercado», Revista Jurídica del

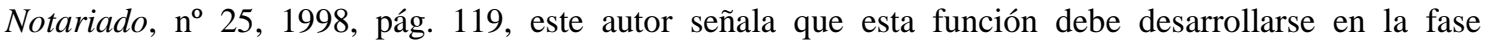
predocumental, documental y postdocumental de la actuación notarial. Por el contrario, AGUILAR BASURTO, L. A., La función notarial: antecedentes, naturaleza y nuevas tendencias de la función notarial, tesis doctoral, Universidad de Salamanca, España, 2014, disponible en: http://hdl.handle.net/10366/123875, consultado 4 agosto 2016, pág. 182 sostiene que el control notarial se configura como un control simultáneo a la celebración o formalización del acto jurídico.

${ }^{4}$ RUEDA PÉREZ, M. A., «La función...», cit., pág. 119. Según PÉREZ DE MADRID CARRERAS, V., Introducción al Derecho Notarial, Sevilla, Academia Sevillana del Notariado, 2006, pág. 85 en el ámbito del control de regularidad o control formal el notario «no valora el fondo del acto o negocio, sino sólo su proyección externa en el tráfico jurídico».

${ }^{5}$ RUEDA PÉREZ, M. A., «La función...», cit., pág. 119; PARRA LUCÁN, M. A., «La responsabilidad civil de notarios y registradores: estudio jurisprudencial», AA. VV. (coord. Moreno Martínez, J. A.), La responsabilidad civil y su problemática actual, Madrid, Dykinson, 2007, disponible en 
Ahora bien, este control de legalidad no puede entenderse de tal forma que acabe convirtiéndose en un control de mérito del negocio que se documenta ${ }^{6}$, ni que que permita al notario denegar su intervención ante de cualquier falta de adecuación a la legalidad por nimia que sea $^{7}$. Se hace necesario, entonces, establecer límites. En este sentido, entendemos adecuados los enunciados por PÉREZ DE MADRID CARRERAS: i) respeto a la intimidad de los otorgantes; ii) respeto a la libertad contractual de las partes, no pudiendo suplantar su voluntad; iii) respeto al equilibrio entre la seguridad jurídica y la celeridad del tráfico y iv) prohibición de actuar como un juez, convirtiendo su intervención en un proceso ${ }^{8}$.

Con base en lo anteriormente señalado podemos ser conscientes de la importancia de la función de control de legalidad en el ámbito notarial. Pero no sólo es una función importante, sino también necesaria. Como ha señalado GARRIDO CHAMORRO, el control de legalidad es en la actualidad mucho más necesario debido al incremento de la conflictividad, la relajación ética de la vida económica, la mayor complejidad en la aplicación del Derecho positivo, las nuevas formas negociales y la necesidad garantizar un equilibrio entre las partes contratantes ${ }^{9}$. Incluso desde la perspectiva del Análisis Económico del Derecho esta función es presentada como uno de los aspectos de la actuación del notario que genera mayores externalidades beneficiosas ${ }^{10}$ y que permiten configurarlo como un gatekeeper $^{11}$. Y es que si no se reconociese al notario una función de control de legalidad se generarían importantes peligros al generarse una apariencia engañosa, pues existiría en el tráfico un documento auténtico, dotado de fe pública y con eficacia privilegiada pero autorizado sin ningún tipo de control ${ }^{12}$. Totalmente rotundo con los efectos perniciosos de la falta de control de legalidad se ha mostrado TENA ARREGUI afirmando que «si no hay control de legalidad, mejor que no haya Notariado» ${ }^{13}$.

http://ebookcentral.proquest.com/lib/bibliotecaudcsp/detail.action?docID=3175819, consultado 12 agosto 2016, págs. 839 y 840; FERNÁNDEZ, T. R. y SAINZ MORENO, F., El notario, la función notarial y las garantías constitucionales, Madrid, Civitas, 1989, págs. 88 y 172.

6 PAZ ARES, C., El sistema notarial: una aproximación económica, Madrid, Colegios Notariales de España, 1995, pág. 104.

${ }^{7}$ RODRÍGUEZ ADRADOS, A., «El principio de legalidad», El notario del siglo XXI, n ${ }^{\circ}$ 15, 2007, disponible en: http://www.elnotario.es/index.php/hemeroteca/revista-15/2289-el-principio-de-legalidad-07787505917053209 , consultado 31 julio 2017.

${ }^{8}$ PÉREZ DE MADRID CARRERAS, V., Introducción ..., cit., pág. 87.

${ }^{9}$ GARRIDO CHAMORRO, P., La función notarial, sus costes y sus beneficios, Madrid, Consejo General del Notariado, 2000, págs. 50 y 51.

${ }^{10}$ GARRIDO CHAMORRO, P., La función ..., cit., pág. 131.

${ }^{11}$ GARRIDO CHAMORRO, P., La función..., cit., pág. 136 y PAZ ARES, C., El sistema ..., cit., pág. 92. Sobre la función del notario como gatekeeper eficiente vid. TENA ARREGUI, R., «La doble vertiente obstaculizadora y reputacional del control de legalidad notarial», Revista Jurídica del Notariado, $\mathrm{n}^{\circ}$ extraordinario, 2012, págs. 234 a 249.

12 VIDAL DOMÍNGUEZ, I., Derecho notarial chileno, Santiago, Legal Publishing, 2015, $2^{\mathrm{a}}$ ed., disponible en: https: proview.thomsonreuters.com/launchapp/title/LALEY/2015/41712394/v1/document/8702B4E1-7F518E8E-A3CF-B68C00A98588/anchor/8702B4E1-7F51-8E8E-A3CF-B68C00A98588, consultado 5 julio 2016; GARRIDO CHAMORRO, P., La función ..., cit., pág. 15.

${ }^{13}$ TENA ARREGUI, R., «La doble...», cit., pág. 240. 


\section{RECONOCIMIENTO LEGAL DE LA FUNCIÓN DE CONTROL DE LEGALIDAD}

Además del reconocimiento doctrinal ${ }^{14}$ y jurisprudencial ${ }^{15}$, la función de control de legalidad está expresamente reconocida tanto en la legislación notarial, como en otras normas sectoriales.

\section{A. LEGISLACIÓN NOTARIAL}

El art. 1 LN señala que el notario «es el funcionario público autorizado para dar fe, conforme a las leyes de los contratos y demás actos extrajudiciales» ${ }^{16}$; el art. 17 bis de esta misma norma dispone que -en los documentos públicos otorgados en formato electrónico- el notario deberá dar fe de que su otorgamiento se adecúa a la legalidad ${ }^{17}$ y

\footnotetext{
${ }^{14}$ AGUILAR BASURTO, L. A., La función..., cit., págs. 182 y 183; CASTRO-GIRONA MARTÍNEZ, J. I., «La seguridad jurídica en el tráfico de bienes y derechos, con especial énfasis en el tema del control de la legalidad y el uso de nuevas tecnologías en el ámbito notarial», Revista Jurídica del Notariado, $\mathrm{n}^{\circ}$ extraordinario, 2010, pág. 63; BALLESTEROS ALONSO, M., «La responsabilidad civil de registradores y notarios», AA. VV. (dir. Álvarez Sánchez, J. I.), La responsabilidad civil profesional, Madrid, Consejo General del Poder Judicial, 2003, págs. 112 y 113; RUEDA PÉREZ, M. A., «La función...», cit., pág. 119; FERNÁNDEZ, T. R. y SAINZ MORENO, F., El notario..., cit., pág. 89; MOLLEDA FERNÁNDEZ-LLAMAZARES, J. A., «La función notarial en la Ley Orgánica y en la actualidad», Revista de Derecho Notarial, $\mathrm{n}^{\circ}$ LXXX, 1973, pág. 385; BELLVER CANO, A., Principios de régimen notarial comparado, Madrid, Gráficas Modelo, ca. 1931, pág. 207. En contra, GARCÍA-ESCÁRRAGA GONZÁLEZ, F., Las condiciones generales en el préstamo hipotecario: su control por notarios y registradores de la propiedad, Madrid, Colegio de Registradores de la Propiedad y Mercantiles de España, 2007, págs. 295 a 299 y MUSTAPICH, J. M., «Concepto del Derecho Notarial», Anales de la Academia Matritense del Notariado, t. X, 1959, pág. 87 quienes niegan que el notario ostente una función de control de legalidad.

${ }^{15}$ STC n ${ }^{\circ}$ 207/1999, 11/11/1999 (RTC 1999/207) señala «la función pública notarial incorpora, pues, un juicio de legalidad sobre la forma y el fondo del negocio jurídico que es objeto del instrumento público, y cabe afirmar, por ello, que el deber del Notario de velar por la legalidad forma parte de su función como fedatario público»; en la misma línea la RDGN 14/11/2007 (RJ 2008/1480) afirma que «el Notario autorizante de la escritura -y con independencia de quien lo elija- tiene el deber "ex lege" de controlar la legalidad del negocio formalizado».

${ }^{16}$ Según CASTRO-GIRONA MARTÍNEZ, J. I., «La seguridad...», cit., págs. 63 y 64 la utilización del plural leyes en este artículo supone que «en su actuación el notario debe tener en cuenta todas las leyes para que los contratos y demás actos extrajudiciales sobre los que recae la fe públicas sean conformes a todas ellas».

${ }^{17}$ No compartimos, por tanto, la interpretación que la Sala Contencioso Administrativa del TS realiza de este artículo en la sentencia 20/5/2008 (RJ 2008/3491) pues considera que la disposición no introduce un control de legalidad ex novo y general para los documentos públicos notariales electrónicos. El TS entiende que el precepto se refiere únicamente al examen de la «adecuación a la legalidad del otorgamiento, es decir, la dación de fe por el Notario de que el otorgamiento ha tenido lugar en las circunstancias que expresa el art. 193, hechas las reservas y advertencias legales a que se refiere el art. 194 y firmada la escritura en la forma dispuesta en el art. 195». Por el contrario, entendemos que -dado que el objetivo del art. 17 bis LN- es que la autorización e intervención notarial en el documento público electrónico esté sujeta a las mismas garantías y requisitos que el documento físico, el hecho de que el notario de fe de que el otorgamiento se adecúa a la legalidad no puede ser entendido en el sentido restringido que mantiene el TS, pues supone una interpretación alejada del sentido literal de la norma. En el mismo sentido se manifiesta CASTRO-GIRONA MARTÍNEZ, J. I., «La seguridad...», cit., pág. 64.
} 
el art. 24 señala que los notarios deberán velar por la regularidad formal y material de los actos y negocios jurídicos que autoricen o intervengan ${ }^{18}$.

Por su parte, el art. 145 RN (en su redacción dada por el Real Decreto 45/2007, de 19 de enero) reconocía de manera expresa la función de control de legalidad del notario y su capacidad para denegar su intervención cuando, a su juicio, ésta supusiera una infracción de la norma legal; pero tales aspectos del precepto fueron declarados nulos mediante STS de 20 de mayo de $2008^{19}$.

Esta decisión no significa que el TS niegue la función de control de legalidad notarial, pues la declaración de nulidad del precepto se basa únicamente en el carácter reglamentario de la norma que lo establece, al ser ésta una materia reservada a la ley ${ }^{20}$. Pero, si bien es cierto que la sentencia no niega esta función, sí hace una interpretación restrictiva de ésta y entiende que habrá de efectuarse únicamente en cuanto venga reconocida por la ley y con el alcance que la norma determine. El mismo razonamiento se utiliza en relación con la denegación de la autorización e intervención del notario; ya que, sin negar tal posibilidad, exige que debe venga amparada por una norma de rango legal. Sin embargo, no podemos compartir la decisión adoptada, pues su aplicación supondría que -en aquellos casos en los que no exista una normativa que de manera específica permita el control de legalidad y la denegación de intervención- el notario no debería realizar el control de legalidad y, en consecuencia, debería dar fe y otorgar carácter público a documentos que recogen situaciones ilegales. Esta posición es más fácilmente comprensible si aplicamos el razonamiento a un supuesto de responsabilidad notarial.

Imaginemos que, siguiendo esta doctrina, el notario -al no existir norma legal expresa que le permita la denegación de su intervención- autoriza un documento que no respeta la legalidad - por ejemplo, autoriza una escritura de constitución de una sociedad anónima en donde no se contienen los estatutos sociales o la identidad de los socios- y ese documento notarial surte efectos en el tráfico causando daños a un tercero. ¿Qué ocurrirá en este supuesto?, ¿quién será responsable?

Si seguimos la interpretación mantenida por el TS no parece que pueda atribuirse la responsabilidad al notario, pues éste ha actuado conforme a su deber. Podría pensarse en atribuir la responsabilidad a la Administración, pero tampoco parece adecuado, al

\footnotetext{
${ }^{18}$ De nuevo, disentimos de la interpretación que el TS ha realizado de este precepto en la sentencia de 20/5/2008 (RJ 2008/3491), pues ha señalado que el alcance del precepto debe ponerse en relación con la finalidad de la norma que estableció su redacción y que era la prevención del fraude fiscal; de manera que entiende que el precepto alude un «genérico deber de los notarios, sin otra concreción sobre su materialización que no sea la especial colaboración con las autoridades judiciales y administrativas, ... que no permite atribuir tampoco a dicho precepto la implantación de un control de legalidad». Sin embargo, in claris non fit interpretatio, el precepto dispone que el notario debe velar por la regularidad formal y material de los actos y negocios que autorice. De igual parecer CASTRO-GIRONA MARTÍNEZ, J. I., «La seguridad...», cit., pág. 65.

${ }^{19}$ Sentencia (Sala Contencioso-Administrativa), 20/5/2008 (RJ 2008/3491). Debemos señalar que no fue anulado y, por lo tanto sigue en vigor, el primer apartado del referido art. $145 \mathrm{RN}$ en donde se dispone que la autorización o intervención del documento público por parte del notario supone el deber de éste de dar de fe -entre otros extremos- de que el otorgamiento se adecúa a la legalidad y a la voluntad informada de los otorgantes e intervinientes.

${ }^{20} \mathrm{Fj}$. $6^{\circ}$. Este mismo argumento ha sido utilizado por el TS (Sala Contencioso-Administrativa), 7/3/2016 (RJ 2016/2182) para declarar la nulidad de los apartados 3 y 4 del art. 30 de la Orden EHA/2899/2011.
} 
haberse excluido la responsabilidad de ésta en los supuestos de actuación notarial tanto doctrinal $^{21}$ como jurisprudencialmente ${ }^{22}$. Puede observarse, entonces, que la decisión adoptada por el TS nos lleva a un camino sin solución; pues no resulta coherente que, siendo el notario el encargado de velar por la seguridad jurídica, se le obligue a autorizar una escritura sabiendo que es ilegal -al no poder rechazar su intervención por no existir norma específica que se lo permita- pero se le haga único responsable por los daños ocasionados. Además, en la medida en que el art. 1 LN configura al notario como el sujeto autorizado para dar fe, conforme a las leyes, de los contratos y demás actos extrajudiciales, no resulta adecuado hacer una interpretación restrictiva de la función carente de base legal. Y es que si el notario no pudiese controlar la legalidad se estaría convirtiendo en un repetidor, en un mero certificador de lo que las partes presentan ante él, vaciándose de sentido la actuación notarial ${ }^{23}$.

Quizás la muestra más clara de la existencia de una función general de control de legalidad se encuentra en el art. 43 dos 2. A) apartado c) Ley 14/2000 que configura como infracción muy grave para el notario la «autorización o intervención de documentos contrarios a lo dispuesto en las leyes o sus reglamentos, a sus formas y reglas esenciales siempre que se deriven perjuicios graves para clientes, para terceros o

${ }^{21}$ SÁNCHEZ MORÓN, M., Derecho de la función pública, Madrid, Tecnos, 2016, $9^{\text {a }}$ ed., págs. 67 y 82; GARCÍA DE ENTERRÍA, E. y FERNÁNDEZ, T. R., Curso de Derecho Administrativo II, Madrid, Thomson Reuters, 2015, 14 ed., pág. 392; PARRA LUCÁN, M. A. y REGLERO CAMPOS, L. F., «La responsabilidad civil de los profesionales del Derecho», AA. VV. (coord. Busto Lagos, J. M. y Reglero Campos L. F.), Tratado de Responsabilidad Civil, t. II, Madrid, Thomson Reuters Aranzadi, 2014, 5 a ed., págs. 510 y 511; SALAS CARCELLER, A., «La responsabilidad civil de los abogados, procuradores y notarios y registradores de la propiedad» en AA.VV. Responsabilidad civil: aspectos fundamentales, Madrid, Sepin, 2007, pág. 434; MAGARIÑOS BLANCO, V., «La función notarial a la luz de las últimas reformas legislativas», Revista Jurídica del Notariado, nº 63, 2007, pág. 214; FERNÁNDEZ HIERRO, J. M., «Responsabilidad civil de los notarios», Jado: Boletín de la Academia Vasca de Derecho, $\mathrm{n}^{\circ}$ 14, 2007, disponible en: https://dialnet.unirioja.es/descarga/articulo/2995607.pdf, consultado 13 de septiembre de 2016, págs. 76 y 77; PARRA LUCÁN, M. A., «La responsabilidad...», cit., págs. 826 y 830; PÉREZ DE MADRID CARRERAS, V., Introducción..., cit., pág. 59; BOLÁS ALONSO, J., La función notarial como factor de seguridad jurídica preventiva del consumidor», La Notaría, nº 1, 1998, disponible en: http://vlex.com/vid/funcion-factor-preventiva-consumidor-233032, VLEX: 233032, consultado 10 enero 2018, pág. 17; RODRÍGUEZ ADRADOS, A., «De nuevo sobre la inescindibilidad notarial», Revista Jurídica del Notariado, n 21, 1997, pág. 186; RODRÍGUEZ ADRADOS, A., «La responsabilidad civil del notario conforme a los artículos 705 y 715 del Código Civil», Revista Jurídica del Notariado, no 24, 1997, pág. 119; FERNÁNDEZ, T. R. y SAINZ MORENO, F., El notario..., cit., págs. 113 y 117; YZQUIERDO TOLSADA, M., La responsabilidad civil del profesional liberal, Madrid, Reus, 1989, pág. 109; RODRÍGUEZ ADRADOS, A., «Sobre las consecuencias de una funcionarización de los notarios», Revista de Derecho Notarial, n ${ }^{\circ}$ CIV, 1979, págs. 339 y 365; GONNELLA, R., «El notario como órgano de la administración de justicia preventiva», Revista de Derecho Notarial, $\mathrm{n}^{\circ}$ XVI, 1957, pág. 205; BELlVER CANO, A., Principios ..., cit., pág. 68. Por el contrario, ROJAS MARTÍNEZ DEL MÁRMOL, Ma DEL P., El ejercicio privado de la fe pública notarial: examen jurídicoadministrativo, Madrid, Marcial Pons, 2003, págs. 400 y 401 propugna la responsabilidad de la Administración por los daños ocasionados en la función notarial en dos supuestos: a) cuando la Dirección General de los Registros y del Notariado no haya adoptado las medidas inspectoras y de sanción oportunas y b) cuando el daño tenga su origen directo o sea consecuencia de una resolución de dicha Dirección General; por su parte BALLESTEROS ALONSO, M., «La responsabilidad...», cit., pág. 107 parece favorable a reconocer al Estado «alguna responsabilidad supletoria o secundaria de la actuación del Notario en los casos en que éste, por un motivo u otro, no llega a dar satisfacción al daño que ha producido».

${ }^{22}$ STS (Sala Contencioso-Administrativo), 13/10/1998 (RJ 1998/9452).

${ }^{23}$ AGUILAR BASURTO, L. A., La función..., cit., pág. 186; TARRAGÓN ALBELLÁ, E., «La función...», cit., pág. 3. 
para la Administración» y el art. 43 dos 2. B) apartado c) de la Ley 14/2000 que configura como infracción grave «las conductas que impidan prestar con imparcialidad, dedicación y objetividad las obligaciones de asistencia, asesoramiento y control de legalidad que la vigente legislación atribuye a los Notarios o que pongan en peligro los deberes de honradez e independencia necesarios para el ejercicio público de su función» y que encuentran su reflejo en los arts. 348 c) y 349 c) Reglamento de Organización y Régimen del Notariado.

\section{B. OTRAS DISPOSICIONES LEGALES}

El reconocimiento la función de control de legalidad no se realiza únicamente en la regulación propiamente notarial, sino también en otras normas; pudiendo citarse como ejemplos:

- El art. 18 de la Ley 2/2009 reguladora de la contratación con los consumidores de préstamos o créditos hipotecarios y de servicios de intermediación para la celebración de contratos de préstamo o crédito, reconoce el deber genérico del notario de controlar la legalidad de los actos y negocios que autoriza y establece su obligación de denegar la autorización de la escritura del préstamo o crédito garantizado con hipoteca cuando no se ajuste a la legalidad y especialmente a los requisitos establecidos en dicha norma ${ }^{24}$.

- El art. 25.4 de la Ley 4/2012 señala que el notario no autorizará la escritura reguladora de un régimen de aprovechamiento por turno mientras no se le acredite el cumplimiento de los requisitos establecidos en los arts. 25.1 y 25.2 de esa norma.

- El art. 20 de la Ley 38/1999 de Ordenación de la Edificación impide que el notario autorice escrituras de declaración de obra nueva sin que se acredite la constitución de las garantías exigidas por el art. 19 de la misma norma.

- El art. 25 de la Ley 43/2003 de Montes impide que el notario autorice escrituras en las que el transmitente no acredite las notificaciones que debe realizar a la Administración pública para que ésta ejerza, en su caso, derechos de adquisición preferente.

- El art. 98 de la Ley 24/2001 que impone al notario, en los casos en que los instrumentos públicos sean otorgados por representantes o apoderados, el deber de realizar un juicio sobre la suficiencia de las facultades representativas de éstos ${ }^{25}$.

- Los arts. 23 LCGC y 80 y 84 TRLGDCU reconocen la función de control de legalidad notarial en el ámbito de las condiciones generales de la contratación y cláusulas abusivas. Precisamente, serán estos artículos los que analicemos a continuación, pues su

\footnotetext{
${ }^{24}$ ALCALÁ DÍAZ, M. A., «Nuevas perspectivas de la función notarial», Anales Academia Matritense del Notariado, tomo L, 2010, pág. 25 ha señalado que en este supuesto el control de legalidad notarial presenta un contenido reforzado orientado a la protección de la parte contractual que tiene la condición de consumidor.

${ }^{25}$ La atribución de este aspecto de la función de control de legalidad material a los notarios ha sido fuertemente cuestionada por los registradores de la propiedad. Sobre este conflicto y su resolución vid. HERNÁNDEZ- TAVERA MARTIIN, V. y MARTÍN- CARO GARCÍA, F., «La competencia exclusiva del notario para verificar la suficiencia de las facultades de los apoderados», Aranzadi Doctrinal, $\mathrm{n}^{\circ}$ 6, 2015, disponible en: www. aranzadidigital.es BIB 2015/1847, consultado 19 octubre 2017.
} 
tratamiento resulta especialmente interesante a la luz de las últimas decisiones del TS y la DGRN.

\section{LA FUNCIÓN DE CONTROL DE LEGALIDAD NOTARIAL DE LAS CONDICIONES GENERALES DE LA CONTRATACIÓN Y LAS CLÁUSULAS ABUSIVAS}

En el ámbito de las condiciones generales de la contratación y las cláusulas abusivas se produce una manifestación de la función de control de legalidad notarial ${ }^{26}$ que viene constituida por: el control de incorporación o inclusión; control de transparencia; control de contenido o abusividad y el mal llamado control de ejecución.

\section{A. CONTROL DE INCORPORACIÓN O INCLUSIÓN}

El art. 23.2 LCGC obliga a que, en el desarrollo de su función, los notarios velen porque las condiciones generales presentes en los documentos que autoricen cumplan con los requisitos de incorporación indicados en los arts. 5 y 7 de la norma. Significa, por tanto, que el notario debe efectivamente controlar que las condiciones generales insertas en los documentos que autorizan estén redactadas de manera transparente, clara, concreta, sencilla y sean legibles, no ambiguas y comprensibles. De esta forma, el art. 23.2 LCGC configura al notario como un auténtico supervisor del cumplimiento de los requisitos de incorporación de las cláusulas abusivas que se contengan en los documentos que autorice $^{27}$. Pero ¿cómo debe actuar el notario para cumplir este deber?

Por una parte, el notario debe garantizar que el adherente tenga acceso físico a las condiciones generales que constan en el contrato, bien sea de modo directo transcribiendo las condiciones- o indirecto -mediante testimonio o copia simple del documento en el que consten ${ }^{28}$. Además, el notario deberá exigir que las condiciones generales insertas en el contrato estén redactadas siguiendo los criterios de claridad y

\footnotetext{
${ }^{26}$ CABANAS TREJO, R. y NAVARRO VIÑUALES, J. M., «La intervención notarial en la nueva Ley sobre Condiciones Generales de la Contratación: una propuesta de reflexión», La Notaría, n ${ }^{\circ}$, 1998, disponible en: http://vlex.com/vid/intervencion-condiciones-propuesta-reflexion-232941 VLEX: 232941, consultado 15 diciembre 2017, pág. 15; SOLÉ RESINA, J., «Comentario al artículo 23», AA. VV. (coord. Arroyo Martínez, I. y Miquel Rodríguez, J.), Comentarios a la Ley de Condiciones Generales de la Contratación, Madrid, Tecnos, 1999, p. 225.

${ }^{27}$ CABANAS TREJO, R. y NAVARRO VIÑUALES, J. M., «La intervención...», cit., pág. 15. Debe recordarse, como señala GONZÁLEZ-MENESES GARCÍA-VALDECASAS, M., «La protección del consumidor y la función notarial (o sobre la crisis de la escritura pública en el mercado financiero», Anales de la Academia Matritense del Notariado, t. LVI, 2016, págs. 758 y 759, que el control de incorporación se produce en todos los supuestos en los que el contrato incluya condiciones generales de la contratación con independencia de la condición subjetiva de la parte contratante; no exigiéndose que sea un consumidor. En este mismo sentido STS 9/5/2013 (RJ 2013/3088) y RDGRN 12/3/2015 (RJ 2015/1586).

${ }^{28}$ SOLÉ RESINA, J., «Comentario ...», cit., pág. 225. El art. 5.2 LCGC permite a los adherentes solicitar al notario que no transcriba las condiciones generales de la contratación en la escritura y se deje constancia de ellas en la matriz incorporándola como anexo. En este caso, el notario tiene la obligación de comprobar que los adherentes conocen íntegramente del contenido de dichas condiciones y que las aceptan.
} 
transparencia exigidos, huyendo de ambigüedades u oscuridades ${ }^{29}$ y que sean legibles. Si el notario realiza estas comprobaciones puede decirse que ha cumplido el deber que el art. 23.2 LCGC le impone.

Cuando el notario considere que la cláusula inserta en el documento que se le presenta para autorizar no ha superado el control de transparencia bien porque es incomprensible, ambigua o ilegible la solución propuesta por SOLÉ RESINA es que el notario deberá eliminar la cláusula del documento a autorizar o, si las partes se oponen, negar la autorización del documento ${ }^{30}$.

\section{B. CONTROL DE TRANSPARENCIA}

Para el supuesto de contratos con consumidores en los que existan condiciones generales de la contratación, el TS en sus sentencias de 9 de mayo de 2013 y 8 de septiembre de $2014^{31}$, establece que además del control de incorporación - y con base en el art. 80.1 TRLGDCU, la Directiva 93/13/CEE y su sentencia de 18 de junio de $2012^{32}$ - debe realizarse el denominado control de transparencia, que supone «el control de comprensibilidad real» de la importancia de la condición general en el desarrollo razonable del contrato ${ }^{33}$. Este control de transparencia se presenta entonces -según ARANGUREN URRIZA- como un control específico y distinto del de incorporación, pues no es un control de claridad formal «sino que determina la transparencia conforme a un parámetro objetivo: el cumplimiento por el empresario predisponente de sus obligaciones sobre transparencia, que se traducen en la idoneidad de la cláusula para que el adherente medio pueda comprender las consecuencias económicas y jurídicas de la cláusula en el desenvolvimiento del contrato» ${ }^{34}$. Nos encontramos, en consecuencia, ante un control diferente del control de inclusión y del control de contenido.

Establecido este novedoso control de transparencia por el TS, la pregunta es si el notario tiene el deber de realizarlo o, por el contrario, debe limitarse a realizar el control de inclusión. Si la respuesta fuese afirmativa, ¿cómo debería llevar a cabo el notario este control de transparencia?

ARANGUREN URRIZA ha entendido que el notario sí debe realizar el control de transparencia y además deberá realizarlo de conformidad con lo exigido en el art. 80.1

\footnotetext{
${ }^{29}$ GARCÍA-ESCÁRRAGA GONZÁLEZ, F., Las condiciones..., cit., pág. 303.

${ }^{30}$ SOLÉ RESINA, J., «Comentario...», cit., pág. 225, debemos señalar que la autora llega a esta conclusión cuando todavía el art. $145.5 \mathrm{RN}$ no había sido declarado nulo. Pero entendemos que a pesar de tal derogación debe llegarse a la misma conclusión, pues el notario no puede autorizar un documento que contravenga la legalidad.

${ }^{31}$ Sentencias (Sala Civil), de 9/5/2013 (RJ 2013/3088) y 8/9/2014 (RJ 2014/4660). En el mismo sentido STS 8/6/2017 (RJ 2017/2509) y 7/11/2017 (RJ 2017/4759).

${ }^{32}$ Sentencia (Sala Civil), de 18 de junio de 2012 (RJ 2012/8857).

${ }^{33}$ Esta misma doctrina ha sido seguida en las resoluciones TS 8/6/2017 (RJ 2017/2509) y 7/11/2017 (RJ 2017/4759)

${ }^{34}$ ARANGUREN URRIZA, F. J., «El notario y los controles de transparencia y abusividad en préstamos hipotecarios con consumidores», Revista Jurídica del Notariado, n ${ }^{\circ}$ 95-96, 2015, pág. 36. En idénticos términos ARANGUREN URIZA, F. J., «Control de transparencia por el notario en préstamos hipotecarios con consumidores», AA. VV. (dir. HORNERO MÉNDEZ, C.), Derecho de contratos: nuevos escenarios y nuevas propuestas, Cizur Menor, Aranzadi, 2017, disponible en: www.aranzadidigital.es BIB 2017/2962, consultado 30 agosto 2018.
} 
TRLGDCU; en consecuencia, el notario debe controlar la claridad, sencillez, accesibilidad, legibilidad de las cláusulas, pero también «emitir un juicio sobre la comprensibilidad real de las mismas, en el sentido de que permiten al prestatario comprender las consecuencias económicas y jurídicas de la cláusula» ${ }^{35}$. En este sentido, compartimos la opinión manifestada por el autor, ya que el control de legalidad que debe realizar el notario ha de extenderse a todas aquellas actuaciones que integran dicho deber; bien sea porque se encuentran establecidas en la ley - como ocurre con el control de inclusión- o bien se deriven de la doctrina jurisprudencial establecida por el TS como el control de transparencia ${ }^{36}$. Esta postura también ha sido adoptada por la DGRN que ha confirmado que el control de transparencia forma parte de los deberes del notario y ha delimitado su contenido ${ }^{37}$. Entendemos entonces que la doctrina jurisprudencial emanada del TS ha impuesto para los notarios un nuevo deber derivado de su función general de control de legalidad, pero siempre teniendo en cuenta que el control de legalidad que realiza el notario no es pleno ${ }^{38}$ ni puede suponer que éste acabe actuando como un juez en la fase previa al conflicto ${ }^{39}$.

\section{CONTROL DE CONTENIDO}

Además de los controles de inclusión y transparencia existe también el control de contenido o abusividad. Este control, encuentra su origen en lo dispuesto en el Título II del TRLGDCU y requiere, según ha señalado la doctrina ${ }^{40}$ y la jurisprudencia del $\mathrm{TS}^{41}$, la concurrencia de los siguientes requisitos:

\footnotetext{
${ }^{35}$ ARANGUREN URRIZA, F. J., «El notario...», cit., pág. 32.

36 Por el contrario, BERROCAL LANZAROT, A. I., «El control de las cláusulas abusivas en los préstamos o créditos hipotecarios. Su eventual nulidad», AA. VV. (dir. Sánchez Ruiz de Valdivia, I. y Olmedo Cardenete, M.), Presente y futuro del mercado hipotecario y Ley de Segunda Oportunidad para consumidores/as y empresarios/as, Cizur Menor, Thomson Reuters, 2015, p. 489 parece configurar el control de transparencia como una atribución exclusiva de los órganos jurisdiccionales.

${ }^{37}$ RDGRN 12/3/2015 (RJ 2015/1586) y 27/10/2015 (RJ 2015/6528) señalan que el deber de transparencia se entiende cumplido, en aquellos supuestos en los que nos encontremos ante la formalización de una hipoteca a la que resulte aplicable la Orden EHA 2899/2011 «con la manifestación expresa por parte del notario de haberse cumplido con las exigencias impuestas por la regulación sectorial; de que la cláusula es clara y comprensible y de que el consumidor puede evaluar directamente, basándose en criterios comprensibles, de las consecuencias jurídicas y económicas a su cargo derivadas de las cláusulas contractuales predispuestas». Por su parte, ARANGUREN URRIZA, F. J., «El notario...», cit., pág. 38 ha señalado que el control de transparencia exige que el notario: a) proporcione una información específica sobre las cláusulas que puedan contener elementos que pueda influir sobre el precio de manera significativa; b) compruebe si dichas cláusulas se incluyeron en la oferta; c) compruebe que las cláusulas estén debidamente resaltadas y se resalte su singularidad y d) advierta sobre la conveniencia de entregar simulaciones en el momento de contratar sobre diferentes escenarios del tipo de interés.

${ }^{38}$ PÉREZ DE MADRID CARRERAS, V., Introducción ..., cit., pág. 23.

${ }^{39}$ RAPOSO FERNÁNDEZ, J. M., «El asesoramiento notarial y la información en los contratos», La Ley: Revista jurídica española de doctrina, jurisprudencia y bibliografía, nº 1,1997, diarios 4228 y 4229 de 13 y 14 de febrero de 1997, pág. 1984.

40 GONZÁLEZ-MENESES GARCÍA-VALDECASAS, M., «La protección...», cit., págs. 762 a 764; SERRANO DE NICOLÁS, A., «Control notarial de las cláusulas abusivas en los préstamos hipotecarios», AA. VV. (dir. Arroyo Amayuelas, E. y Serrano de Nicolás, A.), La europeización del Derecho Privado: cuestiones actuales, Madrid, Marcial Pons, 2016, disponible en: http://www.ub.edu/jeanmonnet_dretprivateuropeu/publicacions/La\%20europeizacion\%20del\%20Derecho \%20privado.pdf, consultado 23 enero 2018, pág. 114.

${ }^{41}$ Entre otras STS 9/5/2013 (RJ 2013/3088).
} 
a) La presencia de un consumidor.

b) La existencia de una condición general predispuesta, destinada a una pluralidad de contratos, no negociada individualmente y que no tenga por objeto una condición esencial del contrato.

c) Que la cláusula, en contra de las exigencias de la buena fe, ocasione un desequilibrio perjudicial para el consumidor e importante en los derechos y obligaciones derivados del contrato.

El control de contenido consiste, tal y como ha señalado la doctrina, en controlar que «las cláusulas del contrato no causen, contra las exigencias de la buena fe, en perjuicio del consumidor, un desequilibrio importante de los derechos y obligaciones de las partes que se deriven del contrato ${ }^{42}$. Pero ¿puede el notario realizar este control de contenido?, ¿podría -teniendo en cuenta la propia esencia de sus funciones- valorar la justicia material de las cláusulas contenidas en el contrato que ante él se pretende otorgar?

La respuesta tradicional a esta pregunta fue que, en este ámbito, la actuación del notario debería limitarse a la actuación dispuesta en el art. 84 TRLGDCU, que prohíbe a los notarios y registradores de la propiedad y mercantiles autorizar o inscribir contratos o negocios que contengan cláusulas declaradas nulas por ser abusivas y que se encuentren inscritas en el $\mathrm{RCGC}^{43}$. Es decir, los notarios deben negarse «categóricamente a autorizar escrituras que contengan cláusulas que ya han sido declaradas nulas por los tribunales» ${ }^{44}$.

Pero el art. 84 TRLGDCU presenta problemas de delimitación que han sido puestos de relieve por GONZÁLEZ-MENESES GARCÍA-VALDECASAS ${ }^{45}$. Así, pensemos en un notario que accede al RCGC para comprobar si una determinada cláusula que se le parece sospechosa ha sido efectivamente inscrita en el RCGC. Cuando comprueba el registro, se percata de que la cláusula sí consta inscrita, pero el predisponente que pretende utilizarla en esta ocasión no es el mismo que el condenado en la sentencia que consta en el registro; ¿debe en este caso el notario denegar la autorización del documento? O por el contrario ¿únicamente debe negarse cuando la cláusula vaya a ser utilizada por el mismo predisponente? Y, ¿qué grado de similitud debe presentar la cláusula para que el notario deniegue su intervención?, ¿la cláusula que se le plantea ha de ser idéntica, debe tener una redacción similar con ligeras modificaciones o puede tener una redacción diferente, pero el mismo contenido sustancial?

LONGO MARTÍNEZ ha señalado -con base en principio de efectividad de la Directiva 93/13/CEE- que el notario debe denegar la inclusión de aquella cláusula que sea

\footnotetext{
${ }^{42}$ GONZÁLEZ-MENESES GARCÍA-VALDECASAS, M., «La protección...», cit., pág. 760.

${ }^{43}$ En el mismo sentido art. 147 RN y 17.2 del Real Decreto $1828 / 1999$, de 3 de diciembre, por el que se aprueba el Reglamento del Registro de Condiciones Generales de la Contratación.

${ }^{44}$ GONZÁLEZ-MENESES GARCÍA-VALDECASAS, M., «La protección...», cit., pág. 786 continúa señalando el autor «es necesario tomar conciencia de que debemos [se refiere a los notarios] ser más inflexibles en este tema. Si una cláusula ha sido declarada nula por abusiva no se puede autorizar escritura alguna que la contengan (siempre que se trate de contratación de adhesión con consumidores). Y no hay más que hablar».

${ }^{45}$ GONZÁLEZ-MENESES GARCÍA-VALDECASAS, M., «La protección...», cit., págs. 781 y 782 nota el pie $n^{\circ} 6$.
} 
idéntica a la que conste inscrita en el RCGC, con independencia de la entidad que pretenda incluirla en el contrato ${ }^{46}$. Es decir, siendo la cláusula idéntica, el notario debe denegar su inclusión en el contrato que se pretende formalizar, ya haya sido predispuesta por la misma entidad que consta condenada en la sentencia inscrita en el RCGC o por otra entidad distinta. Si bien compartimos con el autor la consideración de que la cláusula inscrita en el RCGC debe ser rechazada por el notario con independencia de quien pretenda incluirla, no compartimos su posición en cuanto a la necesidad de que la cláusula inscrita sea idéntica por las razones que se expondrán a continuación ${ }^{47}$.

En resumen, la configuración legal llevó a que la doctrina negase que el notario pudiera realizar el control de contenido, debiendo ceñir su actuación a un deber de colaboración con los tribunales, al entender que solo los órganos jurisdiccionales ostentaban tal control $^{48}$ y únicamente cuando se tratase de cláusulas inscritas en el RCGC podría el notario negarse a su incorporación en el documento que autorizaba.

Esta opinión fue mantenida, además, por la DGRN diversas resoluciones ${ }^{49}$, dictadas con respecto a la competencia del registrador de la propiedad pero que resultan plenamente aplicables al notario. Así la resolución de 19 de abril de 2006 (RJ 200817714) señaló que el registrador no puede configurarse como «una suerte de juez» que declare la nulidad de las cláusulas contractuales por vulnerar la LCGC y la normativa propia del consumidor sin que esa nulidad haya sido declarada previamente en vía judicial.

Sin embargo, cierto sector doctrinal considera que el control de contenido es un control de legalidad; es decir, que el control de contenido es un control de validez de las cláusulas predispuestas y que consecuencia puede ser realizado por aquel que aplica la

\footnotetext{
${ }^{46}$ LONGO MARTÍNEZ, A. A., «El control notarial de las cláusulas abusivas: contenido y fases. Un intento de puesta al día», La Notaría, $\mathrm{n}^{\circ}$ 1, 2014, disponible en: https://libros-revistasderecho.vlex.es/vid/540387574 VLEX: 540387574, consultado 20 diciembre 2017, pág. 78. El autor ha modificado su parecer con respecto a lo señalado en LONGO MARTÍNEZ, A. A., «La obligación notarial de abstención en caso de cláusulas declaradas nulas en sentencia inscrita en el Registro de Condiciones Generales de la Contratación», La Notaría, $\mathrm{n}^{\mathbf{0}}$ 4, 2011, disponible en: https://dialnet.unirioja.es/descarga/articulo/3936583/2.pdf, consultado 19 diciembre 2017, pág.116 en donde afirmaba que el notario tiene la «obligación de no autorizar ni inscribir contratos o negocios jurídicos en los que se pretenda la inclusión de cláusulas declaradas nulas en sentencia inscrita en el RCGC debe entenderse aplicable a aquellos que otorgue el o los predisponentes condenados en la sentencia, pero no a cualesquiera otros posibles predisponentes». Por su parte, CABANAS TREJO, R. y NAVARRO VIÑUALES, J. M., «La intervención...», cit., pág. 20 han señalado que, si cambia el predisponente, el notario podría autorizar la escritura con la advertencia oportuna.

${ }^{47}$ LONGO MARTÍNEZ, A. A., «La obligación...», cit., pág. 116 argumenta que «solo cabe considerar nula la cláusula idéntica a la considerada en la sentencia, puesto que cualquier modificación respecto de esta haría que la misma ya no haya sido objeto de la imprescindible calificación judicial» ${ }^{47}$; sin embargo, y como se verá, en la actualidad ya no es necesario que la cláusula sea idéntica para que el notario rechace su inclusión en el contrato.

${ }^{48}$ CAVALlÉ CRUZ, A., «Función...», cit., pág. 27; LONGO MARTÍNEZ, A. A., «La obligación...», cit., pág.111; SOLÉ RESINA, J., «Comentario a la Disposición Adicional 1ª . Dos. 6» AA. VV. (coord. Arroyo Martínez, I. y Miquel Rodríguez, J.), Comentarios a la Ley de Condiciones Generales de la Contratación, Madrid, Tecnos, 1999, pág. 279; PÉREZ DE MADRID CARRERAS, V., «Protección notarial de los consumidores», El notario del siglo XXI, $\mathrm{n}^{\circ}$ 26, 2009, disponible en: http://www.elnotario.es/index.php/hemeroteca/revista-26/1498-proteccion-notarial-de-los-consumidores0-31670872337809647, consultado 25 enero 2018.

49 RRDGRN 20/5/2008 (RJ 2008\7715); 19/5/2008 (RJ 2008\7714); 16/5/2008 (RJ 2008\3154); 14/5/2008 (RJ 200818279) 8/2/2008 (RJ 2008\639); 1/2/2008 (RJ 20081633); 21/12/2007 (RJ 2008\2086).
} 
ley ${ }^{50}$. Además, como señala ARANGUREN URRIZA, la jurisprudencia europea ${ }^{51}$ ha concluido que el control de abusividad de la cláusula no puede configurarse como un control que sea competencia exclusiva de los jueces «sino que incumbe a todos cuantos deben aplicar el Derecho, entre ellos, notarios y registradores» ${ }^{52}$.

La referida jurisprudencia determinó que la DGRN cambiara radicalmente la concepción que había mantenido hasta el momento- limitando la actuación del notario dentro del ámbito del control de contenido de las condiciones generales en los contratos con consumidores- a partir de las resoluciones de 1 de octubre (RJ 2010/5273) y 4 de noviembre de 2010 (RJ 2011/2461), en donde -como señala CARRASCO PERERAconfigura una nueva doctrina sobre la intervención registral en el control de las cláusulas: la doctrina de la nulidad in claris $^{53}$.

Así, la DGRN permite ahora que el registrador niegue la inscripción cuando la nulidad de la cláusula haya sido declarada por resolución judicial firme, pero además le reconoce también una «mínima actividad calificadora». Este reconocimiento supone que el registrador podrá denegar la inscripción de la cláusula cuando pueda apreciar su abusividad «sin realizar ningún tipo de valoración de las circunstancias concurrentes en el supuesto concreto» ${ }^{54}$.

En consecuencia, la función calificadora del registrador -y por consiguiente del notariodebe limitarse a la «mera subsunción automática del supuesto de hecho en una prohibición específicamente determinada en términos claros y concretos» ${ }^{55}$. Así, el control notarial deberá realizarse únicamente sobre aquellas cláusulas que están afectadas por «una tacha apreciable objetivamente: (porque así resulte claramente de una norma que exprese dicha tacha), sin que puedan entrar en el análisis de aquellas otras que, por tratarse de conceptos jurídicos indeterminados o que puedan ser incluidos en el ámbito de la incertidumbre sobre el carácter abusivo (p.ej., basado en el principio general de la buena fe o el desequilibrio de derechos y obligaciones), sólo podrán ser declaradas abusivas en virtud de una decisión judicial» ${ }^{56}$.

\footnotetext{
${ }^{50}$ MIQUEL GONZÁLEZ, J. M., «Libertad contractual, condiciones generales y control de legalidad», $E l$ notario del siglo XXI, $\mathrm{n}^{\circ} 30,2010$, disponible en: http://www.elnotario.es/index.php/hemeroteca/revista30/1265-libertad-contractual-condiciones-generales-y-control-de-legalidad-0-7112038579873776, consultado 12 enero 2018. En el mismo sentido, pero referido al control notarial de legalidad SERRANO DE NICOLÁS, A., «Control...», cit., pág. 104 y GONZÁLEZ-MENESES GARCÍA-VALDECASAS, M., «La protección...», cit., pág. 756. En contraste, AGÜERO ORTIZ, A., «Nulidad cláusula de gastos III: actuación del notariado», disponible en: http://blog.uclm.es/cesco/files/2017/02/Nulidad-clausula-degastos-III.pdf, consultado 12 enero 2018, pág. 20 señala que el notario debe realizar un control de legalidad y un control de abusividad.

${ }^{51}$ Sentencias Tribunal de Justicia de las Comunidades Europeas asunto C-14/83, Sabine Von Colson y Elisabeth Kamann contra Land Nordrhein-Westfalen y C-243/08, Pannon GSM Zrt. contra Erzsébet Sustikné Györfi.

${ }_{52}^{5}$ ARANGUREN URRIZA, F. J., «El notario...», cit., pág. 16.

${ }^{53}$ CARRASCO PERERA, A., «Comentario a la Resolución de la Dirección General de los Registros y del Notariado de 1 de octubre de 2010», Cuadernos Civitas de Jurisprudencia Civil, nº 86, 2011, pág. 1197.

${ }^{54}$ RDGRN 1/10/2010 (RJ 2010/5273) y 4/11/2010 (RJ 2011/2461).

${ }^{55}$ RDGRN 1/10/2010 (RJ 2010/5273) y 4/11/2010 (RJ 2011/2461).

${ }^{56}$ RDGRN 1/10/2010 (RJ 2010/5273) y 4/11/2010 (RJ 2011/2461). A pesar de su aparente claridad los problemas que presenta la aplicación práctica de esta doctrina han sido puestos de manifiesto por CARRASCO PERERA, A., «Comentario...», cit., págs. 1199 a 1204.
} 
Después de esta etapa inicial, la postura fue mantenida e incluso ampliada -se puede vislumbrar así una segunda fase- en resoluciones como las de 28 de abril (RJ 2015/3300) y 22 de julio de 2015 (RJ 2015/4241) en donde la DGRN señala que el registrador -y en consecuencia el notario- podrá rechazar la inscripción de la cláusula cuando su nulidad se derive de: i) su oposición a una norma imperativa o prohibitiva; ii) una resolución judicial firme o iii) cuando el registrador (en nuestro caso el notario) pueda apreciar la abusividad de forma objetiva, bien porque coincida con alguna de las establecidas en la lista negra del TRLGDCU o porque vulnere alguna norma específica sobre la materia en cuestión.

En la actualidad -que configuraría la tercera fase- la $\mathrm{DGRN}^{57}$ sostiene que el registrador puede rechazar las cláusulas cuya abusividad se derive de su oposición a: i) normas imperativas o prohibitivas expresas y objetivas; ii) una resolución judicial firme -sin necesidad de que conste inscrita en el RCGC- que proceda del TS en cuanto fuente complementaria del Derecho ${ }^{58}$, o responda a un criterio mayoritario y uniforme de los órganos judiciales superiores; o cuando pueda apreciar la abusividad de forma objetiva sin realizar ningún tipo de ponderación, bien porque la cláusula nula coincida con alguna de las establecidas en la lista negra del TRLGDCU o porque vulnere alguna norma específica sobre la materia en cuestión.

En consecuencia, vemos como la inscripción de la sentencia en el RCGC ya no resulta determinante para que el notario pueda denegar su autorización y, como se ha señalado, la inscripción en el RCGC «únicamente tendrá relevancia, desde el punto de vista de la actuación notarial, en los casos de sentencias firmes de tribunales inferiores o, de sentencias aisladas del TS, que no sienten jurisprudencia, que no es el caso de las de Pleno» ${ }^{59}$.

Como podemos observar, la nota común en las tres etapas de la nueva doctrina de la DGRN es que se permite que el registrador -el notario si lo aplicamos a nuestro caso-

\footnotetext{
${ }^{57}$ Resoluciones de 20/6/2016 (RJ 2016/4992); 7/4/2016 (RJ 2016/3229); 17/11/2015 (RJ 2015/6496); 10/11/2015 (RJ 2015/6530); 21/10/2015 (RJ 2015/6493); 25/9/2015 (RJ 2015/4623).

${ }^{58}$ CARRASCO PERERA, A. y AGÜERO ORTIZ, A., «Reflexiones sobre la actuación del notariado ante intereses moratorios que superen en un $2 \%$ a los intereses remuneratorios», disponible en: http://blog.uclm.es/cesco/files/2015/06/Reflexiones-sobre-la-actuaci\%C3\%B3n-del-notariado-anteintereses-moratorios-que-superen-en-un-2-a-los-intereses-remuneratorios__.pdf, consultado 12 enero 2018, pág. 2 consideran, con base en el Acuerdo de la Sala de Gobierno del TS de 19/11/2014 y la sentencia de 11/7/2011 (entre otras), que una única sentencia dictada por el Pleno del TS crea doctrina jurisprudencial y por lo tanto integra el ordenamiento jurídico en cuanto fuente complementaria del Derecho.

${ }^{59}$ OCCA, Consulta 3/2015, disponible en: http://hayderecho.com/wp-content/uploads/2015/05/ConsultaOCCA-3-2015-inteses-demora-prestamos-personales.pdf, consultado 25 enero 2018, pág. 6. AGÜERO ORTIZ, A., "Comentario sobre el Proyecto de Ley de Contratos de Crédito Inmobiliario: La "nueva" obligación de los notarios de controlar la abusividad de las cláusulas», disponible en: http://blog.uclm.es/cesco/files/2017/03/De-nuevo-sobre-el-control-de-transparencia.pdf, consultado 12 enero 2018, pág. 1 resume la doctrina de la DGRN del siguiente modo «la DGRN desde su resolución de 4-11-2010 ha insistido en que el control de legalidad que ha de ser realizado por notarios y registradores incluye el control de abusividad de las cláusulas que sean palmariamente nulas, en el sentido de que su abusividad sea apreciable objetivamente, sin necesidad de ponderación con las circunstancias del caso; o por contravenir la lista negra de cláusulas abusivas; o por haber sido declaradas abusivas por el Tribunal Supremo en Pleno o en reiteradas sentencias; o por ser criterio mayoritario y uniforme de los órganos judiciales superiores; sin estar restringido este deber a que la sentencia que declare su nulidad conste inscrita en el Registro de Condiciones Generales de la Contratación».
} 
niegue la inclusión de la cláusula en aquellos supuestos en que pueda actuar de manera objetiva, sin necesidad de ponderar las circunstancias del caso, para comprobar la abusividad de la cláusula ${ }^{60}$. Pues, como señala LONGO MARTÍNEZ, en los supuestos de determinación indirecta de la abusividad no puede pretenderse que el notario rechace una cláusula por abusiva cuando, para alcanzar esta conclusión necesita apreciar «criterios como ausencia de buena fe o desequilibrio entre las contraprestaciones -caso de la regla general del art. 82.1 TRLDCU- o, en general, de conceptos jurídicos indeterminados -como ocurre con los supuestos de los arts. 85 a 90, calificables como "lista gris"». Pues este tipo de control corresponde exclusivamente a los jueces ${ }^{61}$.

Esta tendencia ha sido - en opinión de ARANGUREN URRIZA ${ }^{62}$ - la aplicada por los notarios en su práctica diaria; de forma tal que éstos han negado la autorización a las cláusulas claramente establecidas como abusivas en el TRLDCU y se han abstenido en los supuestos de cláusulas dudosas o aquellas cuya abusividad requiera valorar la buena fe. Opinión contraria mantiene AGÜERO ORTIZ quien ha afirmado que es habitual que los notarios no realicen el control de abusividad en los términos establecidos por la DGRN - y en consecuencia no nieguen su intervención- si la cláusula sospechosa no estaba inscrita en el RCGC ${ }^{63}$.

Sea como fuere, a pesar de que la doctrina emanada de la DGRN con respecto a la actuación de notarios y registradores en el control de contenido de las cláusulas abusivas pueda parecer clara, lo cierto es que impone a éstos un deber con unos límites enormemente amplios.

Así, el notario deberá rechazar la autorización de aquellos contratos en los que se pretenda incluir alguna cláusula que haya sido declarada nula por abusiva en una sentencia del TS, esté o no inscrita en el RCGC, bastando una sola sentencia de este Tribunal declarando la abusividad para que deba ser considerada por el notario ${ }^{64}$. En consecuencia, el notario debe permanecer atento a todas las sentencias que dicte el TS sobre cláusulas abusivas si no quiere que se le pase por alto la declaración de abusividad de una cláusula, que no la detecte en el contrato que autoriza y en consecuencia incumpla su deber.

\footnotetext{
${ }^{60}$ RDGRN 22/7/2015 (RJ 2015/4241).

${ }^{61}$ LONGO MARTÍNEZ, A. A., «El control...», cit., pág. 78. En el mismo sentido, OLAIZOLA, F., «El necesario control extrajudicial de las cláusulas abusivas», El notario del siglo XXI, n 49, 2013, disponible en: http://www.elnotario.es/index.php/hemeroteca/revista-49/opinion/opinion/3421-elnecesario-control-extrajudicial-de-las-clausulas-abusivas , consultado 25 enero 2018: «los notarios habrán así de denegar la autorización o intervención de aquellas escrituras y pólizas que contengan cláusulas cuyo carácter abusivo pueda ser objetivamente apreciado; y, por el contrario, no podrán entrar a pronunciarse sobre aquellas cláusulas respecto de las que haya que realizar una actividad de ponderación y valoración, para lo que carecen de potestad. Tal es pues, ni menos ni más, el alcance del control notarial de abusividad de las cláusulas que resulta posible conforme a la normativa vigente».

${ }^{62}$ ARANGUREN URRIZA, F. J., «El notario...», cit., pág. 23.

${ }^{63}$ AGÜERO ORTIZ, A., «Comentario...», cit., pág. 1.

${ }^{64}$ CARRASCO PERERA, A. y AGÜERO ORTIZ, A., «Reflexiones sobre la actuación del notariado ante intereses moratorios que superen en un $2 \%$ a los intereses remuneratorios», disponible en: http://blog.uclm.es/cesco/files/2015/06/Reflexiones-sobre-la-actuaci\%C3\%B3n-del-notariado-ante-

intereses-moratorios-que-superen-en-un-2-a-los-intereses-remuneratorios__.pdf, consultado 12 enero 2018, págs. 1 y 2.
} 
Sin embargo, no basta que el notario permanezca atento a las sentencias del TS, sino que también debe tener en consideración aquellas resoluciones judiciales firmes que, no procediendo del Alto Tribunal, respondan «a un criterio mayoritario y uniforme de los órganos judiciales superiores» ${ }^{65}$. Además, deberá tener amplios conocimientos de la normativa aplicable, pues debe rechazar también aquellas cláusulas cuya abusividad se derive de su oposición a normas imperativas o prohibitivas expresas y objetivas. Muy probablemente por la magnitud de la tarea encomendada a los notarios, el Consejo General del Notariado creó en el año 2013 el Órgano de Control de las Cláusulas Abusivas (conocido como OCCA) ${ }^{66}$.

En consecuencia, si aplicamos la doctrina de la DGRN a los supuestos concretos, nos encontramos que - dada la jurisprudencia emanada del TS en sentencias como la de 22 de abril (RJ 2015/1360) y 23 de diciembre de 2015 (RJ 2015/5714)- el notario debe rechazar la autorización del contrato con consumidores en los que se pretendan incluir cláusulas que:

- No hayan sido negociadas e impongan un interés de demora que incremente en más de dos puntos porcentuales el interés remuneratorio pactado en los contratos de préstamo sin garantía real concertados con consumidores.

- Impongan al hipotecante en exclusiva los gastos derivados de la intervención notarial y registral ${ }^{67}$.

- Impongan al consumidor todos los gastos correspondientes a abogado y procurador aun cuando su intervención no fuese obligatoria ${ }^{68}$.

- Impongan a los consumidores las costas de los litigios derivados del incumplimiento de obligaciones por el prestatario ${ }^{69}$.

- Impongan al cliente el pago de todos los tributos que se devenguen como consecuencia del préstamo hipotecario ${ }^{70}$.

La dificultad se presenta en relación con las cláusulas relativas a los intereses de demora en los contratos de préstamos o créditos para adquirir una vivienda habitual garantizados por una hipoteca que grave la vivienda; pues estos intereses -conforme al art. 114.3 LH- no pueden ser superiores a tres veces el interés legal del dinero. Sin embargo, el TS en su sentencia de 23 de diciembre de 2015 (RJ 2015/5714) ${ }^{71}$ considera aplicable a los intereses de demora recién referidos el mismo criterio que el mantenido

\footnotetext{
${ }^{65}$ Resoluciones de 20/6/2016 (RJ 2016/4992); 7/4/2016 (RJ 2016/3229); 17/11/2015 (RJ 2015/6496); 10/11/2015 (RJ 2015/6530); 21/10/2015 (RJ 2015/6493); 25/9/2015 (RJ 2015/4623).

${ }^{66}$ CAVALlÉ CRUZ, A., «Función...», cit., pág. 34. Sobre los objetivos pretendidos por el OCCA vid. mismo autor y obra págs. 35 y 36. La pregunta que dejamos enunciada es si el notario - a pesar de haber incumplido su deber y no detectar la cláusula abusiva en el documento que autoriza- debe ser considerado civilmente responsable. Pues en estos supuestos, a fin de cuentas, quien ha introducido y redactado la cláusula no es el notario sino el predisponente del contrato. ¿Sería aceptable en términos de responsabilidad hacer responder al notario de los daños generados al consumidor cuando únicamente ha realizado su función de control de manera incorrecta pero no ha intervenido en la redacción de la cláusula?

67 AGÜERO ORTIZ, A., «Nulidad de la cláusula de gastos en préstamos hipotecarios: no son sólo abusivos los gastos comprendidos en la STS de 23 de diciembre de 2015 (gastos, efectos y plazos)», Revista CESCO de Derecho de Consumo, $\mathrm{n}^{\mathrm{o}}$ 20, 2016, Disponible en: https://www.revista.uclm.es/index.php/cesco/article/view/1245, consultado 24 enero 2018, pág. 10.

${ }^{68}$ AGÜERO ORTIZ, A., «Nulidad...», cit., pág. 12.

${ }^{69}$ AGÜERO ORTIZ, A., «Nulidad...», cit., pág. 12.

${ }^{70}$ AGÜERO ORTIZ, A., «Nulidad...», cit., pág. 13.

${ }^{71}$ Y reiterada en la STS 3/6/2016 (RJ 2016/2300).
} 
en su sentencia de 22 de abril de 2015 (RJ 2015/1360) con respecto a los intereses moratorios en los préstamos personales; de manera que considera abusiva aquella cláusula que imponga un interés de demora que incremente en más de dos puntos porcentuales el interés remuneratorio pactado. Para justificar su decisión el TS señala que el límite de interés establecido en el art. 114.3 LH «no tiene como función servir de pauta al control judicial de las cláusulas abusivas, sino fijar criterio para un control previo del contenido de la cláusula, en vía notarial y registral, de modo que las condiciones generales que excedan de dicho límite, ni siquiera tengan acceso al documento contractual, ni en su caso resulten inscritas» ${ }^{72}$.

Si conjugamos esta declaración del TS con la doctrina que la DGRN ha mantenido con respecto a la actuación de los notarios en el control de abusividad -que determina que éstos deban rechazar las cláusulas cuya nulidad se derive de su oposición a: i) alguna norma específica sobre la materia o ii) a una resolución firme del pleno del TS- la situación se complica. Pues, en el caso de los intereses de demora en los préstamos hipotecarios, la normativa específica -art. $114.3 \mathrm{LH}$ - establece que no pueden ser superiores a tres veces el interés legal del dinero mientras que la sentencia del Pleno del TS considera abusiva la cláusula que en los préstamos hipotecarios imponga un interés de demora que supere en dos puntos el interés remuneratorio pactado. El problema se plantea cuando en un contrato de préstamo, establecido un interés remuneratorio del $3 \%$, se pretende incluir una cláusula con un interés moratorio del $7 \%$. Pues este interés supera en más de dos puntos el interés remuneratorio pero no es superior en tres veces el interés legal del dinero (9\%). ¿Qué debe hacer el notario en estos casos?, ¿debe aplicar la doctrina del TS y denegar la inclusión de la cláusula o debe aplicar la normativa específica y no oponerse a la cláusula pretendida? ${ }^{73}$.

Entendemos que en supuestos como el planteado, dada la doctrina del TJUE sobre el principio de efectividad en la protección de los derechos de los consumidores ${ }^{74}$ y el deber de especial asistencia a la parte necesitada de ella que recae sobre el notario ${ }^{75}$, éste debe aplicar la opción que proporcione una mayor protección al consumidor, lo que llevaría a aplicar la doctrina del TS sobre intereses moratorios en los préstamos hipotecarios y en el supuesto planteado supondría negar su autorización a la cláusula que pretenda establecer unos intereses moratorios del 7\%. Los criterios anteriormente señalados - principio de efectividad en la protección de los derechos del consumidor y especial asistencia al otorgante necesitado de ella- pueden servir de pauta orientadora en todos aquellos supuestos en que se presenten dudas sobre la aplicación del control de contenido que debe realizar el notario.

Realizado el control por parte del notario en los términos expuestos, si la cláusula resulta abusiva, deberá denegar su inclusión en el documento que se pretende autorizar; ahora bien, LONGO MARTÍNEZ -a la luz de ciertas situaciones: como aquella en que

\footnotetext{
${ }^{72}$ STS 23/12/2015 (RJ 2015/5714).

${ }^{73}$ NIETO CAROL, U., «A favor de: Justicia encargará a notarios y registradores el control de cláusulas abusivas», Actualidad Jurídica, n 906, 2015, disponible en: www. aranzadidigital.es BIB 2015\1903, consultado 22 enero 2017.

${ }^{74}$ A título ejemplificativo sentencias TJUE C-169/14, caso Juan Carlos Sánchez Morcillo y otros contra Banco Bilbao Vizcaya Argentaria (TJCE 2014/106) y C-49/14, Finanmadrid E.F.C. contra Jesús Vicente Albán Zambrano y otros (TJCE 2016/53).

75 Art. 147 RN. Sobre el deber de especial asistencia al otorgante necesitado de ella vid. BOLÁS ALONSO, J., «La función...», cit.
} 
una persona física ante las dificultades de pago de la hipoteca inicial concurre junto con la entidad financiera para firmar una ampliación de su hipoteca inicial, la prórroga de su plazo y una nueva cuota- considera que la obligación del notario debe entenderse cumplida -siempre que el predisponente de la cláusula no sea aquel que haya sido condenado en sentencia por su abusividad- si hacen constar en la escritura las oportunas advertencias sobre la cláusula en cuestión, previa información al deudor sobre la misma y cuando éste a pesar de la advertencia, manifieste su voluntad expresa de vincularse al contrato. Fundamenta su postura con base la finalidad de la TRLDCU, que no es otra que la protección del adherente y consumidor (elemento que considera cumplido con la advertencia que constará en la escritura) y con la necesidad de conciliar ese objetivo con el respeto a la voluntad de los contratantes ${ }^{76}$.

\section{EL DENOMINADO CONTROL DE EJECUCIÓN}

Como consecuencia de la modificación introducida en el art. 129.2.f) LH, por la Ley $1 / 2013$ de 14 de mayo, que permite al notario -en los supuestos de venta extrajudicial del bien- poner en conocimiento del deudor, del acreedor, del avalista e hipotecante -en su caso- la presencia de cláusulas abusivas en el préstamo hipotecario cuando éstas constituyan el fundamento de la venta extrajudicial o hubiesen determinado la cantidad exigible, LONGO MARTÍNEZ ha considerado que se atribuye al notario el denominado control de ejecución ${ }^{77}$.

Sin embargo, en nuestra opinión, no nos encontramos ante un auténtico control de ejecución, sino que la tarea que desempeña el notario es una labor de información ${ }^{78}$, puesto que lo único que puede realizar es advertir al deudor, acreedor, avalista e hipotecante sobre el carácter abusivo de ciertas cláusulas, pero no puede denegar su intervención. En consecuencia, advertido el prestatario será éste quien decida si plantea la cuestión ante al juez competente o no.

\footnotetext{
${ }^{76}$ LONGO MARTÍNEZ, A. A., «La obligación...», cit., págs. 108 y 116. El autor postula también esta solución cuando el notario tenga dudas sobre la identidad de la cláusula que se pretende inscribir y la declarada nula debiendo, en estos casos, la advertencia hacer referencia a la «posible nulidad de la cláusula». Por su parte, SEDA HERMOSÍN, M. A., «Cláusulas abusivas y control notarial», AA.VV. (dir. SÁNCHEZ RUIZ DE VALDIVIA, I. y OLMEDO CARDENETE, M.), Presente y futuro del mercado hipotecario y Ley de Segunda Oportunidad para consumidores/as y empresarios/as, Cizur Menor, Thomson Reuters, 2015, pp. 184 a 187 realiza una valoración crítica de la función de control de abusividad atribuida al notario y reclama «instrumentos verdaderamente eficaces para prevenir y depurar las cláusulas abusivas».

${ }^{77}$ LONGO MARTÍNEZ, A. A., «El control...», cit., págs. 76 y 82. El mencionado art. 129.2.f) también atribuye al notario la facultad de suspender la venta extrajudicial del bien cuando cualquiera de las partes presente ante el juez competente una cuestión sobre el carácter abusivo de la cláusula. Aspecto éste que no trataremos en este trabajo.

${ }^{78}$ CASADO CASADO, B., «Función notarial y cláusulas abusivas en la venta extrajudicial del bien», Revista de Derecho Patrimonial, $\mathrm{n}^{\circ}$ 42, 2017, pág. 171 considera que se trata de una función de advertencia referida únicamente a las cláusulas no declaradas abusivas en sede judicial; pues, en su opinión, una interpretación sistemática, lógica y teleológica del precepto, lleva a que el notario debiera poder suspender la venta extrajudicial cuando esta contenga «cláusulas declaradas abusivas, cláusulas insertas en la lista negra de cláusulas abusivas o cláusulas manifiestamente contrarias a la norma imperativa».
} 
Nos encontramos entonces ante una nueva manifestación de la función de información cuya introducción en el ordenamiento español es relativamente reciente y novedosa ${ }^{79}$ y en la que -a diferencia de los controles de inclusión, transparencia y abusividad- el notario no puede denegar su intervención en el acto, ni suspenderlo, sino que debe limitarse a poner en conocimiento del deudor el posible carácter abusivo de la cláusula. En caso de que el prestatario interponga la acción correspondiente, será el juez quien resuelva sobre el carácter abusivo en el procedimiento judicial ${ }^{80}$, lo que pone de relieve que el artículo no reconoce al notario una función de control de legalidad ${ }^{81}$.

\section{CONCLUSIONES}

Los notarios ostentan una función de control de legalidad - tanto en su aspecto formal como material- de los actos en los que intervienen, por lo que no pueden otorgar carácter público a aquellos documentos que vulneren la legalidad vigente. Debido al carácter general con que se recoge esta función en los arts. 1 y 24 LN entendemos que ésta debe impregnar toda actuación notarial, sin que se requieran normas que en cada ámbito de actuación notarial atribuyan dicha función.

La función de control de legalidad notarial ha alcanzado especial relevancia en relación con las condiciones generales de la contratación y las cláusulas abusivas. Así, entendemos que, en este ámbito, el notario debe realizar controles de incorporación, de transparencia y de contenido dentro de los límites señalados con anterioridad. Consideramos especialmente interesante, por su amplitud, la configuración del control de contenido realizada por la última doctrina de la DGRN y que exigirá a los notarios un conocimiento continuo y actualizado sobre la jurisprudencia y la normativa relativa a las cláusulas abusivas; al tiempo que proponemos la utilización del principio de efectividad en la protección de los derechos de los consumidores y el desempeño de la función notarial de especial asistencia al otorgante necesitado de ella como criterios orientadores ante las dificultades plantee la aplicación del control notarial de contenido.

\section{BIBLIOGRAFÍA}

AGÜERO ORTIZ, A., «Comentario sobre el Proyecto de Ley de Contratos de Crédito Inmobiliario: La "nueva" obligación de los notarios de controlar la abusividad de las cláusulas», disponible en: http://blog.uclm.es/cesco/files/2017/03/De-nuevo-sobre-elcontrol-de-transparencia.pdf, consultado 12 enero 2018.

\footnotetext{
79 CASADO CASADO, B., «Función notarial y cláusulas abusivas en la venta extrajudicial del bien», Revista de Derecho Patrimonial, 2017, nº 42, pp. 156 y 157.

${ }^{80}$ CARRASCO PERERA, A.; CORDERO LOBATO, E. y MARÍN LÓPEZ, M. J., Tratado de los derechos de garantía, t. I, Cizur Menor, Thomson Reuters, 2015, $3^{\mathrm{a}}$ ed., pág. 1154; GONZÁLEZMENESES GARCÍA-VALDECASAS, M., «La protección...», cit., pág. 785; LONGO MARTÍNEZ, A. A., «La obligación...», cit., pág. 89; CASADO CASADO, B., «Función...», cit., págs. 157 y 167.

${ }^{81}$ CASADO CASADO, B., «Función...», cit., pág. 171.
} 
AGÜERO ORTIZ, A., «Nulidad cláusula de gastos III: actuación del notariado», disponible en: http://blog.uclm.es/cesco/files/2017/02/Nulidad-clausula-de-gastosIII.pdf, consultado 12 enero 2018.

AGÜERO ORTIZ, A., «Nulidad de la cláusula de gastos en préstamos hipotecarios: no son sólo abusivos los gastos comprendidos en la STS de 23 de diciembre de 2015 (gastos, efectos y plazos)», Revista CESCO de Derecho de Consumo, $\mathrm{n}^{\circ}$ 20, 2016, Disponible en: https://www.revista.uclm.es/index.php/cesco/article/view/1245, consultado 24 enero 2018.

AGUILAR BASURTO, L. A., La función notarial: antecedentes, naturaleza y nuevas tendencias de la función notarial, tesis doctoral, Universidad de Salamanca, España, 2014, disponible en: http://hdl.handle.net/10366/123875, consultado 4 agosto 2016.

ALCALÁ DÍAZ, M. A., «Nuevas perspectivas de la función notarial», Anales Academia Matritense del Notariado, tomo L, 2010.

ARANGUREN URIZA, F. J., «Control de transparencia por el notario en préstamos hipotecarios con consumidores», AA. VV. (dir. HORNERO MÉNDEZ, C.), Derecho de contratos: nuevos escenarios y nuevas propuestas, Cizur Menor, Aranzadi, 2017, disponible en: www.aranzadidigital.es BIB 2017/2962, consultado 30 agosto 2018.

ARANGUREN URRIZA, F. J., «El notario y los controles de transparencia y abusividad en préstamos hipotecarios con consumidores», Revista Jurídica del Notariado, $\mathrm{n}^{\circ}$ 95-96, 2015.

BALLESTEROS ALONSO, M., «La responsabilidad civil de registradores y notarios», AA. VV. (dir. Álvarez Sánchez, J. I.), La responsabilidad civil profesional, Madrid, Consejo General del Poder Judicial, 2003.

BELLVER CANO, A., Principios de régimen notarial comparado, Madrid, Gráficas Modelo, ca. 1931.

BERROCAL LANZAROT, A. I., «El control de las cláusulas abusivas en los préstamos o créditos hipotecarios. Su eventual nulidad», AA. VV. (dir. Sánchez Ruiz de Valdivia, I. y Olmedo Cardenete, M.), Presente y futuro del mercado hipotecario y Ley de Segunda Oportunidad para consumidores/as y empresarios/as, Cizur Menor, Thomson Reuters, 2015.

BOLÁS ALONSO, J., «La función notarial como factor de seguridad jurídica preventiva del consumidor», La Notaría, $\mathrm{n}^{\circ}$ 1, 1998, disponible en: http://vlex.com/vid/funcion-factor-preventiva-consumidor-233032， VLEX: 233032, consultado 10 enero 2018.

CABANAS TREJO, R. y NAVARRO VIÑUALES, J. M., «La intervención notarial en la nueva Ley sobre Condiciones Generales de la Contratación: una propuesta de reflexión», La Notaría, no 5, 1998, disponible en: http://vlex.com/vid/intervencion- 
condiciones-propuesta-reflexion-232941 VLEX: 232941, consultado 15 diciembre 2017.

CARRASCO PERERA, A., «Comentario a la Resolución de la Dirección General de los Registros y del Notariado de 1 de octubre de 2010», Cuadernos Civitas de Jurisprudencia Civil, nº 86, 2011.

CARRASCO PERERA, A.; CORDERO LOBATO, E. y MARÍN LÓPEZ, M. J., Tratado de los derechos de garantía, t. I, Cizur Menor, Thomson Reuters, 2015, $3^{\mathrm{a}}$ ed.

CARRASCO PERERA, A. y AGÜERO ORTIZ, A., «Reflexiones sobre la actuación del notariado ante intereses moratorios que superen en un $2 \%$ a los intereses remuneratorios», disponible en: http://blog.uclm.es/cesco/files/2015/06/Reflexionessobre-la-actuaci\%C3\%B3n-del-notariado-ante-intereses-moratorios-que-superen-en-un2-a-los-intereses-remuneratorios__.pdf, consultado 12 enero 2018.

CASADO CASADO, B., «Función notarial y cláusulas abusivas en la venta extrajudicial del bien», Revista de Derecho Patrimonial, nº 42, 2017.

CASTRO-GIRONA MARTÍNEZ, J. I., «La seguridad jurídica en el tráfico de bienes y derechos, con especial énfasis en el tema del control de la legalidad y el uso de nuevas tecnologías en el ámbito notarial», Revista Jurídica del Notariado, n⿳亠 extraordinario, 2010 .

CAVALLÉ CRUZ, A., «Función notarial y protección del consumidor», Revista del OCCA (Órgano de Control de Cláusulas Abusivas), $\mathrm{n}^{\circ}$ 1, 2014, disponible en: http://www.occa.notariado.org/liferay/c/document_library/get_file?uuid=0de83c53cb69-4e78-aaf9-6a166f03b885\&groupId=5857552, consultado 11 enero 2018.

DE LA CÁMARA ÁLVAREZ, M., «El notario latino y su función», Revista de Derecho Notarial, $\mathrm{n}^{\circ}$ LXXVI, 1972.

FERNÁNDEZ, T. R., y SAINZ MORENO, F., El notario, la función notarial y las garantías constitucionales, Madrid, Civitas, 1989.

FERNÁNDEZ HIERRO, J. M., «Responsabilidad civil de los notarios», Jado: Boletín de la Academia Vasca de Derecho, $\mathrm{n}^{\mathrm{o}}$ 14, 2007, disponible en: https://dialnet.unirioja.es/descarga/articulo/2995607.pdf, consultado 13 de septiembre de 2016.

GARCÍA DE ENTERRÍA, E. y FERNÁNDEZ, T. R., Curso de Derecho Administrativo II, Madrid, Thomson Reuters, 2015, $14^{\mathrm{a}}$ ed.

GARCÍA-ESCÁRRAGA GONZÁLEZ, F., Las condiciones generales en el préstamo hipotecario: su control por notarios y registradores de la propiedad, Madrid, Colegio de Registradores de la Propiedad y Mercantiles de España, 2007.

GARRIDO CHAMORRO, P., La función notarial, sus costes y sus beneficios, Madrid, Consejo General del Notariado, 2000. 
GONNELLA, R., «El notario como órgano de la administración de justicia preventiva», Revista de Derecho Notarial, $\mathrm{n}^{\mathrm{o}} \mathrm{XVI}, 1957$.

GONZÁLEZ-MENESES GARCÍA-VALDECASAS, M., «La protección del consumidor y la función notarial (o sobre la crisis de la escritura pública en el mercado financiero», Anales de la Academia Matritense del Notariado, t. LVI, 2016.

HERNÁNDEZ- TAVERA MARTÍN, V. y MARTÍN- CARO GARCÍA, F., «La competencia exclusiva del notario para verificar la suficiencia de las facultades de los apoderados», Aranzadi Doctrinal, $\mathrm{n}^{\circ}$ 6, 2015, disponible en: www. aranzadidigital.es BIB 2015/1847, consultado 19 octubre 2017.

LONGO MARTÍNEZ, A. A., «El control notarial de las cláusulas abusivas: contenido y fases. Un intento de puesta al día», La Notaría, no 1, 2014, disponible en: https://librosrevistas-derecho.vlex.es/vid/540387574 VLEX: 540387574, consultado 20 diciembre 2017.

LONGO MARTÍNEZ, A. A., «La obligación notarial de abstención en caso de cláusulas declaradas nulas en sentencia inscrita en el Registro de Condiciones Generales de la Contratación», La Notaría, $\mathrm{n}^{\circ} \quad 4, \quad 2011, \quad$ disponible en: https://dialnet.unirioja.es/descarga/articulo/3936583/2.pdf, consultado 19 diciembre 2017.

MADRIDEJOS FERNÁNDEZ, A., «Disposición Adicional 1 ${ }^{\mathrm{a}}$. Dos: Art. 10.6 LGDCU», AA. VV. (coord. BERCOVITZ RODRÍGUEZ-CANO, R.), Comentarios a la Ley de Condiciones Generales de la Contratación, Pamplona, Aranzadi, 1999.

MAGARIÑOS BLANCO, V., «La función notarial a la luz de las últimas reformas legislativas», Revista Jurídica del Notariado, nº 63, 2007.

MIQUEL GONZÁLEZ, J. M., «Libertad contractual, condiciones generales y control de legalidad», El notario del siglo XXI, $\mathrm{n}^{\circ}$ 30, 2010, disponible en: http://www.elnotario.es/index.php/hemeroteca/revista-30/1265-libertad-contractualcondiciones-generales-y-control-de-legalidad-0-7112038579873776, consultado 12 enero 2018.

MOLLEDA FERNÁNDEZ-LLAMAZARES, J. A., «La función notarial en la Ley Orgánica y en la actualidad», Revista de Derecho Notarial, nº LXXX, 1973.

MUSTAPICH, J. M., «Concepto del Derecho Notarial», Anales de la Academia Matritense del Notariado, t. X, 1959.

NIETO CAROL, U., «A favor de: Justicia encargará a notarios y registradores el control de cláusulas abusivas», Actualidad Jurídica, $\mathrm{n}^{\circ}$ 906, 2015, disponible en: www. aranzadidigital.es BIB 2015\1903, consultado 22 enero 2017.

OCCA, Consulta 3/2015, disponible en: http://hayderecho.com/wpcontent/uploads/2015/05/Consulta-OCCA-3-2015-inteses-demora-prestamos-

personales.pdf, consultado 25 enero 2018. 
OLAIZOLA, F., «El necesario control extrajudicial de las cláusulas abusivas», El notario del siglo XXI, $\mathrm{n}^{\mathrm{o}}$ 49, 2013, disponible en: http://www.elnotario.es/index.php/hemeroteca/revista-49/opinion/opinion/3421-elnecesario-control-extrajudicial-de-las-clausulas-abusivas, consultado 25 enero 2018.

PARRA LUCÁN, M. A. y REGLERO CAMPOS, L. F., «La responsabilidad civil de los profesionales del Derecho», AA. VV. (coord. Busto Lagos, J. M. y Reglero Campos L. F.), Tratado de Responsabilidad Civil, t. II, Madrid, Thomson Reuters Aranzadi, 2014, $5^{\mathrm{a}}$ ed.

PARRA LUCÁN, M. A. «La responsabilidad civil de notarios y registradores: estudio jurisprudencial», AA. VV. (coord. Moreno Martínez, J. A.), La responsabilidad civil y su problemática actual, Madrid, Dykinson, 2007, disponible en http://ebookcentral.proquest.com/lib/bibliotecaudcsp/detail.action?docID=3175819, consultado 12 agosto 2016.

PAZ ARES, C., El sistema notarial: una aproximación económica, Madrid, Colegios Notariales de España, 1995.

PÉREZ DE MADRID CARRERAS, V., «Protección notarial de los consumidores», El notario del siglo XXI, $\mathrm{n}^{\circ}$ 26, 2009, disponible en: http://www.elnotario.es/index.php/hemeroteca/revista-26/1498-proteccion-notarial-delos-consumidores-0-31670872337809647, consultado 25 enero 2018.

PÉREZ DE MADRID CARRERAS, V., Introducción al Derecho Notarial, Sevilla, Academia Sevillana del Notariado, 2006.

RAPOSO FERNÁNDEZ, J. M., «El asesoramiento notarial y la información en los contratos», La Ley: Revista jurídica española de doctrina, jurisprudencia y bibliografía, $\mathrm{n}^{\circ}$ 1,1997, diarios 4228 y 4229 de 13 y 14 de febrero de 1997.

RODRÍGUEZ ADRADOS, A., «El principio de legalidad», El notario del siglo XXI, $\mathrm{n}^{\circ}$ 15, 2007, disponible en: http://www.elnotario.es/index.php/hemeroteca/revista-15/2289el-principio-de-legalidad-0-7787505917053209, consultado 31 julio 2017.

RODRÍGUEZ ADRADOS, A., «La responsabilidad civil del notario conforme a los artículos 705 y 715 del Código Civil», Revista Jurídica del Notariado, nº 24, 1997.

RODRÍGUEZ ADRADOS, A., «De nuevo sobre la inescindibilidad notarial», Revista Jurídica del Notariado, $\mathrm{n}^{\circ}$ 21, 1997.

RODRÍGUEZ ADRADOS, A., «Sobre las consecuencias de una funcionarización de los notarios», Revista de Derecho Notarial, $\mathrm{n}^{\circ}$ CIV , 1979.

ROJAS MARTÍNEZ DEL MÁRMOL, M. ${ }^{a}$ DEL P., El ejercicio privado de la fe pública notarial: examen jurídico-administrativo, Madrid, Marcial Pons, 2003.

RUEDA PÉREZ, M. A., «La función notarial en la economía de mercado», Revista Jurídica del Notariado, $\mathrm{n}^{\circ}$ 25, 1998. 
SALAS CARCELLER, A.,_«La responsabilidad civil de los abogados, procuradores y notarios y registradores de la propiedad» en AA.VV. Responsabilidad civil: aspectos fundamentales, Madrid, Sepin, 2007.

SÁNCHEZ MORÓN, M., Derecho de la función pública, Madrid, Tecnos, 2016, 9ª ed.

SEDA HERMOSÍN, M. A., «Cláusulas abusivas y control notarial», AA.VV. (dir. SÁNCHEZ RUIZ DE VALDIVIA, I. y OLMEDO CARDENETE, M.), Presente y futuro del mercado hipotecario y Ley de Segunda Oportunidad para consumidores/as y empresarios/as, Cizur Menor, Thomson Reuters, 2015.

SERRANO DE NICOLÁS, A., «Control notarial de las cláusulas abusivas en los préstamos hipotecarios», AA. VV. (dir. Arroyo Amayuelas, E. y Serrano de Nicolás, A.), La europeización del Derecho Privado: cuestiones actuales, Madrid, Marcial Pons, 2016, disponible en: http://www.ub.edu/jeanmonnet_dretprivateuropeu/publicacions/La\%20europeizacion\% 20del\%20Derecho\%20privado.pdf, consultado 23 enero 2018.

SOLÉ RESINA, J., «Comentario al artículo 23», AA. VV. (coord. Arroyo Martínez, I. y Miquel Rodríguez, J.), Comentarios a la Ley de Condiciones Generales de la Contratación, Madrid, Tecnos, 1999.

SOLÉ RESINA, J., «Comentario a la Disposición Adicional 1 $1^{\text {a }}$. Dos. 6» AA. VV. (coord. Arroyo Martínez, I. y Miquel Rodríguez, J.), Comentarios a la Ley de Condiciones Generales de la Contratación, Madrid, Tecnos, 1999.

VALLET DE GOYTISOLO, J., «La función notarial de tipo latino», Revista de Derecho Notarial, $\mathrm{n}^{\circ} \mathrm{C}, 1978$.

TARRAGÓN ALBELLÁ, E. «La función notarial: su fundamento. Concepto de notario; examen del artículo 1 del Reglamento Notarial. Características del notariado latino», AA. VV. (coord. Borrell, J.), Derecho Notarial, Valencia, Tirant lo Blanch, 2011, disponible en: http://www.tirantonline.com TOL2.226.452, consultado 23 agosto 2016.

TENA ARREGUI, R., «La doble vertiente obstaculizadora y reputacional del control de legalidad notarial», Revista Jurídica del Notariado, nº extraordinario, 2012.

UNIÓN INTERNACIONAL DEL NOTARIADO, «Principios de la función», disponible en: http://www.uinl.org/principios-de-la-funcion, consultado 10 agosto 2017.

VIDAL DOMÍNGUEZ, I., Derecho notarial chileno, Santiago, Legal Publishing, 2015, $2^{\text {a }} \quad$ ed., disponible en: https://proview.thomsonreuters.com/launchapp/title/LALEY/2015/41712394/v1/docum ent/8702B4E1-7F51-8E8E-A3CF-B68C00A98588/anchor/8702B4E1-7F51-8E8EA3CF-B68C00A98588, consultado 5 julio 2016.

YZQUIERDO TOLSADA, M., La responsabilidad civil del profesional liberal, Madrid, Reus, 1989. 